ред. В. О. Фесюка. К.: ТОВ «ПІДПРИЄМСТВО «ВІ ЕН ЕЙ», 2016. C. $166-173$.

5. Паспорт річки Турія /Акціонерне товариство інститут «Волнньводпроект». Луцьк. 1994. 200 с.

6. Постанова Кабінету Міністрів України № 391 від 30 березня 1998 року «Про затвердження Положення про державну систему моніторингу довкілля» II Офіиійний вісник Украӥни. 1998. № 13. С. 91-97.

DOI https://doi.org/10.30525/978-9934-26-006-3-38

\title{
ТЕНДЕНЦІЇ У РОЗПОВСЮДЖЕННІ ВІДКЛАДЕНЬ ОЖЕЛЕДІ НА ТЕРИТОРІЇ УКРАЇНИ У ЗИМОВІ МІСЯЦІ ПРОТЯГОМ 2011-2019 рр. ВІДНОСНО ПЕРІОДУ 1981-2010 рр.
}

\author{
Пясецька C. I. \\ кандидат географічних наук, \\ старший науковий співробітник \\ Украӥнський гідрометеорологічний інститут \\ Державної служби Украӥни з надзвичайних ситуацій \\ та Національної академії наук України \\ м. Київ, Украӥна
}

Відкладення ожеледі відносяться до несприятливих погодних явищ, які перешкоджають роботі ряду гагузей економіки, що є найбільш погодозалежними від них - енергетика транспорт, комунальне господарство. Дослідження розповсюдження таких видів відкладень на території України було започатковано О.М. Раєвським на початку 60-х років XX сторіччя та продовжено у роботах В.М. Бабіченко для періоду 80-90-х років XX та початку XXI ст. відносно відкладень ожеледі стихійного характеру (СГЯ) [1-3].

Натепер, для визначення поточних тенденцій у розповсюдженні відкладень ожеледі на території Украни на сучасному етапі зміни клімату протягом 2011-2019 pp. необхідно продовжити таке дослідження та провести порівняння середньої кількісті випадків таких відкладень за цей період відносно рекомендованого ВМО 30-и річчя протягом 1981-2010 рр. Необхідність такого порівняння визначено суттєвими змінами у сучасній кліматичній системі внаслідок 
потепління, що триває. Порівняння було здійснено для зимових місяців, для яких випадки відкладень ожеледі найбільш типові.

Січень. Протягом 2011-2019 рр. відносно 1981-2010 рр. на більшій частині території України переважали додатні відхилення середньої кількості випадків відкладень ожеледі. На території західних та північно-західних областей спостерігався значний осередок таких відхилень, який охоплював значні частини територій Житомирщини, Волині (більшу частину за виключенням території поблизу Луцька), Тернопільшини, Хмельниччини, Чернівеччини, Івано-Франківщини, частини Львівщини поблизу Львова та на їі південно-західної частини. Основні центри таких відхилень середньої кількості випадків відкладень ожеледі спостерігались на півночі Волині, північному сході Рівненщини, на півночі та заході Житомирщини. У західних областях виділялись центри значних додатних відхилень середньої кількості випадків відкладень ожеледі у північному заході Львівщини, півночі Хмельниччини та у центрі та півдні Тернопільщини. Цей осередок продовжується на території Івано-Франківської та Чернівецької областей. На Закарпатті найбільш помітний осередок додатних відхилень розташований на північно-західній частині області. Осередок від’ємних відхилень середньої кількості випадків відкладення ожеледі розташований на південному заході Закарпаття. Майже не змінилась середня кількість випадків відкладень ожеледі на південному сході Волинської області, на півдні Рівненщини, півночі та південному заході Львівщини, а також на значній частині території Закарпаття. У північному та північно-східному регіоні розповсюдження осередка додатних відхиленеь спостерігалось на території на північному західної Київщини, півночі та центрі Чернігівщини, на сході Сумщини, півночі та заходу Харківщини. Осередок на півночі Чернігівщини та на території Сумщини та Харківщини продовжується у своїй південній частині у бік Полтавщини, Черкащини, Кіровоградщини, Дніпропетровщини та пов'язаний на сході із північчю Луганщини та західною частиною Донеччини і Запоріжжям. Осередок від'ємних відхилень знаходиться на південому заході та півдні Київської області. На сході країни розповсюдження додатних відхилень спостерігалось на півночі та заході Луганщини, заході та півдні Донеччини. Осередок від'ємних відхилень знаходиться у східній частині обох областей та охоплює територію у напрямку 3 півночі на південь. У центральному регіоні спостерігалось осередки додатних відхилень на території Вінниччини, особливо у центрі та на сході, а інший на території Черкащини, Кіровоградщини, Полтавщини та Дніпропетровщини (особливо у їх 
центрі, сході та півдні). Незначні від'ємні відхилення спостерігались на заході Черкащини та на північному заході Кіровоградщини. На півдні країни значні осередки додатних відхилень спостерігались на півночі Одещини, на північному сході Миколаївщини, сході та півдні Херсонщини.

Лютий. На території північно-західних та західних областей спостерігались ряд осередків додатних відхилень середньої кількості випадків відкладень ожеледі. Незначні за територією та інтенсивністю такі осередки спостерігались на території Житомирщини, Рівненщини та Львівщини. Найбільший їх осередок знаходиться на території Тернопільщини, Івано-Франківщини, Чернівеччини та Закарпаття. Малопотужні осередки від'ємних відхилень середньої кількості випадків відкладень ожеледі спостерігаються на півночі Житомирщини, та на Волині. Такі осередки виявлено на півдні Львівщини та Закарпаття. Найбільший за площею осередок таких відхилень існує на більшій частині Хмельниччини та півдні Житомирщини. Він розповсюджується на північно-західну частину Вінничини, а на сході переходить на територію півдня Київщини. На півночі та північному сході осередки додатних відхилень спостерігаються на території північно-східної частини Київщини, півночі, центру та півдня Чергігівщини, сходу Сумщини, півночі та заходу Харківщини. Незначні осередки від'ємних відхилень спостерігались на півдні Київщини, поблизу Чернігова, на півночі Сумщині. На Харківщині осередки від'ємних відхилень на північному сході області. На сході країни спостерігаються осередки додатних відхилень на півночі Луганщини, а також на півдні Донеччини. Осередок від'ємних відхилень охоплює південну частину Луганщини та східну частину Донеччини. У центрі України осередки додатних відхилень розташовані на території Вінничини, Черкащини, Кіровоградщини Полтавщини та Дніпропетровщини. Західна частина цього осередку знаходиться у південно-східній частині Вінницької області. Цей осередок має своє продовження на півночі Одеської області. На території Полтавської області такий осередок відмічається в районі Лубен та Кобеляк. На Дніпропетровщині подібний осередок знаходиться на лівобережжі області та поєднується на півночі із ареалом розповсюдження додатних відхилень на території півдня Харківської області. Осередки від'ємних відхилень спостерігаються на півночі Вінницької області, півночі та заході Черкаської області, півдні Полтавщини, центрі Дніпропетровщини. На сході України у осередки додатних відхилень виявлено на півдні Луганської області, а 
на Донеччині на південному сході області. Осередок від'ємних відхилень середньої кількості випадків відкладень ожеледі знаходиться на півдні та центрі Луганської та сході Донецької області. У південному регіоні осередки додатних відхилень спостерігались на півночі Одеської області, а також на їі південному заході. На території інших південних областей величини додатних відхилень були незначними. Осередки від'ємних відхилень на території південних областей спостерігались на південному сході Одещини, а також на півдні Миколаївщини, півночі та південному сході Херсонщини. На Запоріжжі подібний осередок здебільшого розташований у центрі та частково на півдні.

Грудень. Протягом грудня 2011-2019 рр. відносно 1981-2010 pp. осередки додатних відхилень середньої кількості випадків відкладень ожеледі спостерігаються на території північно-західних та західних областей, вони займають Житомирщину, східну частину Рівненщини, більшу частини Хмельниччини та Тернопільщини, Чернівеччину та південний схід Івано-Франківщини, північний схід та південний захід Львівщини, а також північний захід Закарпаття. Осередки від’ємних відхилень середньої кількості випадків відкладень ожеледі спостерігались у цетрі Житомирщини, на Рівненщині та Волині 3 центром у Луцьку. На Львівщині осередок таких відхилень спостерігається на північному заході. На Івано-Франківщині осередок від’ємних відхилень відмічався на півночі та північному сході, а на Закарпатті в районі півнчно-західної частини та на південному заході. На півночі та північному сході країни осередки додатних відхилень спостерігались на півночі та північному заході Київщини, півночі та центру Чернігівщини, півночі Сумщини, півночі та сходу Харківщини. Осередки від'ємних відхилень середньої кількості випадків відкладень ожеледі спостерігаються в ряді областей - на півдні Київської, заході Чернігівщини, на північному заході та на сході Сумщини. Незначний осередок від'ємних відхилень спостерігається на південному заході Харківщини. На сході України осередки додатних відхилень розташовувались на території півночі Луганщини та півдня та південного заходу Донеччини. Осередки від'ємних відхилень сконцентровані на півдні Луганщини та сході Донеччини. У центрі осередки додатних відхилень розташовувались на більшій частині Вінничини, заход та півдні Черкаської, більшій частині Кіровоградської (особливо центр та південь), південний схід частині Полтавщини та Дніпропетровщини. Осередки від'ємних відхилень середньої кількості випадків відкладень ожеледі спостерігались на північному сході 
Вінничини, півночі Черкащини, півдні Полтавщини, в окремих регіонах півдня Кіровоградщини та на півночі Дніпропетровщини. На півдні країни осередки додатних відхилень середньої кількості відкладень ожеледі спостерігались на північному заході Одещини, півночі Миколаївщини, північно-східна та південна частини Херсонщини, північний захід та центр Запоріжжя. Осередки від'ємних відхилень спостерігаються на території Одещини від північного сходу на південь та на крайньому південному заході. На Миколаївщині такий осередок знаходиться на північному сході області. На Херсонщині такий осередок знаходиться на південному сході області, а на Запоріжжі від іiі східу на південь.

Отже, протягом окремих місяців 2011-2019 рр. на території України відносно 1981-2010 pр. середня кількість випадків відкладень ожеледі найбільше збільшилась у січні та грудні де переважали осередки додатних відхилень. У лютому разом із осередками додатних відхилень спостерігалась значна кількість осередків від'ємних, які займали значні площі на території ряду областей України, та перевищували площі додатних відхилень.

\section{Література:}

1. Стихийные метеорологические явления на Украине и Молдавии / Под ред. В.Н. Бабиченко. - Л. : Гидрометеоиздат, 1991. $-223 \mathrm{c}$.

2. Клімат України / За ред.. В.М. Ліпінського, В.А. Дячука, В.М. Бабіченко. - К.: Вид-во. Раєвського, 2003. - 343 с.

3. Стихійні метеорологічні явища на території України за останнє двадцятиріччя (1986-2005 рр.) / За ред. В.М. Ліпінського, В.І.Осадчого, В.М. Бабіченко. - К. : Вид-во Ніка-Центр, 2006. - 311 с. 